\title{
Business Capital Going to the Countryside Practice, Problems and Countermeasures-Based on the Perspective of Cooperatives
}

\author{
Gan $\mathrm{Yi}^{1, \mathrm{a}, *}$, Jiao Yinghui ${ }^{2, \mathrm{~b}}$ \\ ${ }^{1}$ School of Finance, Jiangxi Normal University, Nanchang, Jiangxi, China \\ ${ }^{2}$ School of Finance, Jiangxi Normal University, Nanchang, Jiangxi, China \\ a*921871598@qq.com \\ b1972948054@qq.com
}

\begin{abstract}
Rural capital and peasant cooperatives are two major forces in the development of rural economy and industry. The state attaches great importance to the healthy development of the two. The rush of industrial and commercial capital to the countryside, on the one hand, revitalized the living capital of rural industries, on the other hand, it also brought many problems. In view of its shortcomings, expanding cooperatives in practice is seen as a way to break through its limitations. This article takes industrial and commercial capital to the countryside as the starting point, and takes Tantou Village in Zishan Town as an empirical object. It understands the development of local industrial and commercial capital and cooperatives, focuses on analyzing the impact of rural and rural capital on the locality, and proposes a path to strengthen cooperatives. Help with problem resolution on a larger scale.
\end{abstract}

Keywords: capital goes to the countryside, farmer's cooperatives, land transfer

\section{工商资本下乡实践概况、问题与对策探究一一基于合作 社壮大视角}

甘益 ${ }^{1,}$ 蕉迎辉 ${ }^{2, b}$

1 江西师范大学财政金融学院, 南昌, 江西, 中国

2 江西师范大学财政金融学院, 南昌, 江西, 中国

$a^{*} 921871598 @ q q . c o m$

b1972948054@qq.com

\section{摘要}

下乡资本与农民合作社是农村经济产业发展中存在的两大力量, 国家对两者的良态发展予以高度重视。 工商资本涌向农村，一方面为乡村产业振兴盘活了资金活水，另一方面也带来了诸多问题。针对其弊 端, 壮大合作社被视为突破其限制的方法。本文以工商资本下乡为切入点, 以梓山镇潭头村为实证对 象, 了解当地工商资本和合作社发展概况、有侧重地分析下乡资本对当地的影响, 提出壮大合作社的 路径, 以期为当地乃至更大范围内的问题解决提供帮助。

关键词: 资本下乡，农民合作社，土地流转

\section{1. 导言}

乡村振兴是一项复杂的系统工程, 重点是产业要振 兴, 产业要兴旺。一个地区的产业如何盘活, 很大程度 上依靠资金的投入，资金活，则产业活。引入社会资本 业已成为农村产业建设的重要力量, 国家在上层建筑层
面也支持社会资本下乡参与农村建设。2018 年中央一 号文件就指出, 要 “鼓励社会各界投身乡村建设” , 依 靠 “投资兴业” 的方式服务乡村振兴事业。倡导资本下 乡在预期上对解决农业生产与发展过程中遇到的融资 难、增收难与难以规模化生产这几类制约农业生产发展 的主要问题发挥着重要作用, 有其必要性。

资本在下乡之后，因自身经营的成熟度、与当地实 
销售的农业公司以及部分种养大户, 当地民众亦在政府

际情况的切合度、政府政策效用的发挥度等因素而产生 的效益大不相同。现实中一方面在部分地区, 资本或是 使当地原有的 “特色” 放大，或是定位出新的 “特色”, 探索出适宜的振兴模式。而另一方面我国各地区现实状 况不尽相同, 在一些地区资本下乡后农民将土地进行流 转，但资本参与建设效益差、基地反复易主，“跑路” “欠租” “收入低” 等问题凸显, 百姓从中获益极其有 限。资本下乡能够促进农村产业结构调整, 创建了一批 新产业、新业态; 农民收入得到提高的同时生活状况得 到改善, 城乡差距缩小。但也有学者指出资本下乡过程 中所暴露的不足，农地“非粮化” “非农化”危害了粮 食安全、抬高了土地的流转价格、损害了农民的利益, 要 “立即纠正 “扶持龙头公司带小农” 的错误政策”。

${ }^{[1]}$ 在鼓励资本参与农村建设的同时, 国家也在不断强调 “要重视培育家庭农场、农民合作社等新型经营主体”。 针对资本下乡弊端, 运用集体的力量, 壮大农民合作组 织被视为突破资本下乡限制的方法。合作社可提高农民 的集中程度, 改善农民所处的不利话语地位, 降低市场 交易成本等。

基于此, 本文将以于都县梓山镇潭头村为实例具体 讨论资本下乡在其中的参与机制, 分析企业与合作社的 关系, 有侧重地探讨资本下乡对当地的影响, 针对工商 资本在支撑当地可持续发展中存在的复制性差、未来走 向波动性强等不足，提出壮大合作社的路径，促进产业 振兴、乡村振兴, 实现农业农村农民发展最优化。

\section{2. 潭头村乡村振兴及资本下乡概况}

\section{1. 潭头村概况}

潭头村位于江西省赣州市于都县梓山镇, 到 2017 年村中有 754 户家庭 3059 人, 主导产业为农业, 种植 富硒蔬菜、葡萄、水稻等。

在战争创伤、自然条件等的影响下, 潭头村长期位 于贫困村的行列, 部分群众居住条件差, 村中基础设施 薄弱, 流传着这样一句古浐语—— “梓山潭头, 吃苦两 头; 晴三天, 挑烂肩头; 雨三天, 水进灶头”。住房、 饮水、内涝等更是困扰几代人的问题。

梓山镇全域土壤富含硒元素, 发展特色农业、现代 农业产业优势凸显, 蔬菜产业尤其是富硒蔬菜产业被定 位为全县现代农业重中之重, 潭头村的招商引资、土地 流转等工作都围绕壮大蔬菜产业开展。梓山镇以产业扶 贫为龙头, 结合多种扶贫形式建立“造血型”扶贫机制, 以 “龙头企业+合作社+农户” 的产业振兴模式前进。截 止到 2017 年，全村建档立卡的贫困户全部脱贫，村中 公路、沟渠、网络、通水等基础设施建设得到质的提升, 人民生活水平得到显著提高。

\section{2. 工商资本和合作社的关系}

参与潭头村发展振兴的工商资本主要是从事果蔬
的帮助之下发展起农民合作社, 以下将介绍两方力量及 其中的关系。

\subsection{1 蔬菜基地的运作模式}

江西金瑞盛、江苏启东谱辉、山东寿光苏成等企业 与梓山镇签下合作项目, 共同打造万亩绿色蔬菜产业带。 潭头村 785 亩耕地现已流转给种养大户, 建立了包括金 瑞盛蔬菜基地在内的数家主要基地。政府负责农户的土 地流转思想工作，企业负责整合农户的土地，并建立现 代化设施完善的农业大棚、生态旅游区和农业展示区。 当地居民的住房可以申请开设农家乐餐厅, 农村借宿等 等。三个企业各自对自己征地范围内的农户支付土地流 转租金, 每亩流转土地价格为 500 斤稻谷的当年价格。

企业的收入来源一共包括三点: 其一富硒蔬菜的销 售收入, 其二大棚及其设备的出租收入, 其三展览区的 门票收入、游乐设施的收入。同时还有三点隐形收入: 其一, 政府给予企业的政策优待。包括税收等方面, 其 二, 展览区对于企业的合作伙伴和潜在的客户起到了一 种广告作用, 同样创造了免费的商业价值。其三，梓山 蔬菜基地名于精准扶贫项下的县内重点工程, 借势政府 部门的社会公信力, 为企业带来商誉。

\section{2.2 合作社参与状况}

基于用工形势和脱贫需要, 潭头村积极探索建立合 作社, 目前在潭头村的合作社中, 分为劳务和种养两类。

劳务合作社。其成立较好地解决了农村劳动力外流 导致的劳力相对不足且留守劳务闲暇时间不确定的问 题。其中潭头村就吸纳了包括 58 名贫困群众在内的劳 动力, 并要求今后基地及村里所涉用工一律在劳务合作 社优先考虑。合作社按照群众意愿及实际情况组建了包 括种植、搬运等在内的 4 支劳务工作队，向用工单位提 供劳务输出, 既满足了企业的用工需要, 又增加群众收 入。

种养合作社。村中积极响应国家 “一村一品” 的号 召, 成立 “一村一品” 种养合作社, 所有贫困户全部入 社。合作社方面负责组织收购、销售成员种养的作物、 离畜, 采购供应其所需的生产资料, 为其提供相关服务。 社员通过合作社入股龙头企业获得分红。建立种养合作 社，使得村民的人均纯收入得到进一步提高。

\subsection{3 双方关系}

从上面关于两方的介绍可知, 合作社提供劳务和社 员种养的作物, 龙头企业加以购买, 年末对合作社入股 社员进行派发分红。潭头村的农民合作社是近些年才发 展起来的, 组织化程度较低, 存在着人才梯队断层、合 作社资金不足、合作社治理机制不合理、销售网络缺乏 的问题, 在和企业的力量对比中处于不利的地位。合作 


\section{2 存在资本垄断农业风险}

密。再进一步扩大来说, 农户和企业之间, 农户通过土 地流转获得租金, 经由合作社入股基地分红或是在基地 务工。大多数农户也仅参与生产环节, 资本对普通农户 处于支配的有利地位。

\section{3. 资本下乡过程中对当地的影响}

以下分析资本下乡对当地带来的积极与消极影响, 其中着重分析弊端, 以期更好地针对不足提出出路。积 极影响中, 最为直观的便是拓宽就业渠道, 增加农民收 入。农民如今可从以下三个方面获得经济收入: 土地流 转所得租金、入股所获分红、务工所得。其次推动了农 业规模化组织化经营, 龙头企业通过土地流转, 整合集 中土地资源, 实现农业连片经营。潭头村将耕地流转建 立果蔬基地, 大面积种植作物, 提高了生产效率。此外, 当地的现代农业产业得到发展, 潭头村及周边村已形成 万亩富硒蔬果产业, 积极发展生态旅游项目。同时优化 基础设施建设, 促城乡融合。村庄因招商引资以及改善 人居生活环境的需要完善相关的配套措施, 同时下乡资 本也会完善基础设施, 带动了乡村基础设施的新一轮完 善。在看到诸多积极面时, 亦不能回避其造成的消极影 响。

\section{1 农业生产 “非粮化”}

通过资本下乡, 调整农业产业结构, 发展经济作物 是潭头村发展现代农业的重要内容。资本具有逐利性, 传统的粮食作物种植并不能满足企业的需求, 经济作物 的种植面积大幅增加, 发展生态旅游亦使多方获利增加。 潭头村农业生产 “非粮化”, 传统以粮食种植为主的农 业结构正发生变化。在我国严守 18 亿亩耕地红线的当 下, 农地流转过程中的 “非粮化” 和 “非农化” 现象无 疑是与农地流转初衰一一整合土地资源, 保护农地背道 而驰的。此外, 部分流转的土地因过度开发肥力下降或 复用率变低, 再度进行农业生产受阻, 资本离开之后损 害的依旧是农民利益。以上的种种情况在很大程度上损 害着国家粮食安全。

虽然目前富硒蔬菜供不应求, 富硒概念的确值得人 们为之付出更高的代价, 但现如今富硒蔬菜的价位已经 高于普通蔬菜数倍, 富硒蔬菜内在价值和企业营销包装 的附加价值能否支撑住富硒蔬菜的高价位? 一旦有大 批富硒蔬菜出现并造成价格冲击, 抑或有新的健康概念 提倡其他微量元素导致富硒概念在市场失宠都会导致 富硒蔬菜价格的大幅度回落。一旦价格回落形成, 农户 和企业的利润会随着售价的回落而迅速回落, 挫伤其生 产积极性。企业方面将面临着低收高成本的现象, 而企 业又是精准扶贫项下的, 其一旦停止经营会造成大量失 业, 脱贫农户将重新返贫。
相关学者研究表明, “兼业农户中的务农劳动力主 要还在从事初级农产品的生产, 资本则主导了农产品的 加工和经营。农产品加工和经营环节的利润被资本占 有。” ${ }^{[2]}$ 结合实际情况, 在潭头村 “龙头企业+合作社+农 户”的发展模式中, 村中过半数的土地都已被流转承包, 农户所参与的多是作物、禽畜种养环节, 很难进入附加 值更高的加工和流通环节, 分享更多的收益。此外村中 的合作社和基地对接, 所种植的作物在很大程度上需要 依靠龙头企业销售, 这使得他们对龙头企业产生依赖性。 依靠外来资本具有极大的不稳定性, 某些资本进行政策 投机㩲取国家惠农资源, 在获利之后 “抛荒” “违约”, 极大地损害了农民的权益, 增加了农村社会不稳定因素。 而其中的原因主要是参与主体未形成真正的利益共同 体, 利益联结不够紧密。

\section{3 农村贫富差距进一步加大}

在原本的乡村社会中就有着 “大农” 和 “小农”之 分, “大农们” 在生产资料及其采购能力、人际关系、 市场信息, 企业家才能等方面相较于小农处于优势地位。 村中原有的大农往往更易于和部门或资本勾结, 壮大自 身的实力。此外村中一部分存在资源优势的农户, 对优 势加以合理利用并发挥, 例如发展农家乐创收, 资源充 足且善于利用者与资源有限者之间形成了更大的差距。 如村民 S, 是红军后代且年轻时参军, 2019 年习近平总 书记考察潭头村时就专门探望了他家。凭借“红色基因” 以及习主席的到访, 很多学校到潭头村开展研学活动, $\mathrm{S}$ 家成了孩子们的课堂, 其兄弟合伙开的超市、农家乐 都火起来了。

以上这两种情况都会进一步加重村中的贫困分化, 多数村民的收入或许是多了, 但贫富差距程度再次拉大 了。

\section{4农民获利程度小，保障作用低}

前文已提到兼业农户务农劳动力主要还在从事初 级农产品的生产, 获得固定土地租金, 不能分享经营收 入。农民所获得的利润处于最末端, 获利程度低。从模 式上看原有耕地的农户可以选择到基地做工亦可进城 务工, 可是对于村中劳动能力低就业能力差的农户, 仅 靠流传出去的土地租金生活将难以为继。相对原有的收 入来源途径, 现有的 “龙头企业+合作社+农户” 的模式 确实拓宽了收入来源渠道, 但是租金却取代土地成为他 们的升级保障。根据马土金等人的研究, “土地保障” 是 “硬保障”，是农民可以控制的安身立命之处; 租金 是软保障, 是农民无法施加任何影响的市场。 ${ }^{[3]}$ 流转了 的土地对于农民的保障功能将不复存在, 依靠务工所得 和土地流转租金农民获得了更多的金钱, 可当风险一旦 来临, 农民将金钱花费使用完毕, 而此时土地的使用权 
民的组织化程度，增强农民的主体地位。三是重视合作

也不属于自己。他本可以靠自行种植作物获得淣底的保 障, 可此时这安身立命的最后一道防线也不复存在了, 农民成为了没有土地这一生产要素的 “无产阶级”。

\section{4. 壮大合作社, 共赢结硕果}

潭头村 “龙头企业+合作社+农户”这一类发展模式 “可以有机整合农户经营、合作经营、公司经营”。 ${ }^{[4]}$ 合 作社可提高农民的集中程度, 改善农民所处的不利话语 地位，降低市场交易成本等。在 “鼓励资本下乡” 和 “积 极培育新型经营主体” 同时倡导的当前, 合作社应该由 各方协力壮大, 促进下乡资本与农户的共同、良态发展。 在集体、合作社先行的情况下号召农户的参与, 塘约村 靠集体化合作社将村民的力量集合起来, 由贫困村变为 小康村，也证明了合作社是一条实际可行的道路。

在潭头村的模式实践中, 各主体利益机制不够紧密, 大部分农户仅停留在底层利润空间小的生产端, 合作社 在其中发挥的作用较小。针对当地发展, 政府加大合作 社扶持力度比如免费教授科学育苗技术等, 继续完善乡 村基础设施建设, 推动合作社壮大。合作社可以 “乘政 策之东风”，利用好国家的扶助资金，在吸收村内资金 来源时可以邀请当地收入相对较高的人群, 以活络资金 来源, 保证合作社资金畅通，延伸产业链。同时亦可以 吸收外部的力量协助合作社进行管理。当地金融机构应 以主体提供金融贷款服务, 依据潭头实际情况推出相应 的产品服务。

我们国家的合作社在实际的运作中, 实践与制度话 语日趋背离。合作社创立总量虽不断增多, 但其中有很 多是名不副实、“空心化” 的存在，本应该作为合作社 主体的农户却毫无话语权，出现了诸多实践问题。合作 社沦为包装资本的工具，农民大户和资本相主导，本应 作为参与主体的农民不仅参与及获利有限, 反倒利益受 损。学界有观点认为合作社只是在部门、资本与小农中 间增加了一个类似于合伙制企业的中间商, 其并不能解 决小农在市场上的弱势地位, 也不能帮助小农参与分享 社会平均收益。 ${ }^{[5]}$ 对于更大范围存在的问题, 首先政府 应该继续鼓励壮大合作社发展，对于社会精英、乡村能 人要肯定他们带领农民发展合作社的积极作用, 发挥他 们的带动作用。同时要出台切实可行的方案, 强化对合 作社发展专项资金的使用监督, 对原有标准较低的合作 社准入门槛进行优化提升。其次, 积极引导农民合作社 兴办加工流通, 加强农民在产业链中的参与程度。可为 合作社开拓市场, 培育市场品牌提供更多的渠道对接及 专家指导。对于让农民分享二三产业增值受益的合作社， 应予以大力支持, 进行经验总结帮助形成可复制的推广 模式。合作社方面, 应建立科学的发展框架, 确定可持 续的盈利模式。一是在合作社管理中可结合社会资本的 力量, 融入公司化的运营方式, 吸纳外部的力量如聘请 职业经理人协助合作社进行管理、产业模式的构建, 积 极探索进入生产、流通、加工等多种领域, 增强自身的 实力和吸引力。二是合作社内部要保持资金链的畅通, 延伸产业链，利用好国家的相关扶持政策发展，增强农
社内部的文化建设, 给予农民相应的技术支持和培训, 培育新型农民主体, 为建设现代农业和社会主义新农村 提供人力保障。

\section{REFERENCES}

[1] Li C.P. (2008) The issue of agriculture, countryside and farmers, China should avoid the second in the Philippines. J. Study Monthly, 07: 25.

[2] Tong Z.H, Wen T.J. (2009) The path to the organization of capital and departments to the countryside and the economy of small farmers - and to question the path of professional cooperatives. J. Open Times, 04: 5-26.

[3] Ma T.J, Tan S.W, Li Z.Y. (2014) The Impact of Industrial and Commercial Capital Going to the Countryside on the Development of "Agriculture, Rural Areas and Farmers": A Case Study of Longan County, Guangxi. J. Beijing Agriculture, 36: 328-330.

[4] Huang Z.H. (2013) Development of Farmers' Professional Cooperatives, Innovative Agricultural Industrialization Business Model. J. Journal of Hunan Agricultural University (Social Sciences), 14 (04): 8-9.

[5] Wen T.J. (2013) Difficulties and outlets for the development of farmer cooperatives. J. Journal of Hunan Agricultural University (Social Sciences), 14 (04): 4-6. 